\title{
PENGARUH PENERAPAN MODEL PEMBELAJARAN PROBLEM BASED LEARNING TERHADAP KEMAMPUAN REPRESENTASI MATEMATIS SISWA SEKOLAH DASAR
}

\author{
Muhammad Hayun dan Azizah Mutiara Syawaly \\ Fakultas Ilmu Pendidikan \\ Universitas Muhammadiyah Jakarta \\ mhayyun@umj.ac.id \\ azizahmsy@gmail.com
}

\begin{abstract}
The aims of this study is to determine the effect of the Problem Based Learning (PBL) learning model on the mathematical representation abilities of students at elementary school 5th level on floor plans and scales. The method used in this research is quasi experimental with a total sample size of 42 students consisting of 22 students of the experimental class and 20 students of the control class with the design of Nonequivalent Control Group Design. The results of the research can be seen from the results of the calculation with the independent $t$ test and obtained $t$ count of 3.497, which means that it is greater than t table 2.021, with a significance level of $0.001<0.05$, this means that there is a significant difference between students in the experimental class and students in the class. control. It can be interpreted that there is an influence of the Problem Based Learning learning model on the mathematical representation ability of fifth grade students of Al-Musyarrofah Islamic Elementary School. The results of this study are expected to be useful for related parties who can use it such as the principal, teachers, students, and further researchers.
\end{abstract}

Keywords: PBL Model, Mathematical Representation Ability, Elementary School (SD)

\section{ABSTRAK}

Penelitian ini bertujuan untuk mengetahui pengaruh model pembelajaran Problem Based Learning (PBL) terhadap kemampuan representasi matematis siswa kelas $V$ materi denah dan skala. Metode yang digunakan dalam penelitian ini adalah quasi eksperimental dengan jumlah sampel sebanyak 42 siswa yang terdiri dari 22 siswa kelas eksperimen dan 20 siswa kelas kontrol dengan desain Nonequivalent Control Group Design. Hasil penelitian dapat terlihat dari hasil perhitungan dengan uji t independen dan diperoleh thitung sebesar 3,497 yang artinya lebih besar dari ttabel2.021, dengan taraf signifikansi 0,001 <0,05, hal ini berarti bahwa ada perbedaan yang signifikan antara siswa di kelas eksperimen dengan siswa di kelas kontrol. Dapat disimpulkan bahwa terdapat pengaruh model pembelajaran Problem Based Learning terhadap kemampuan representasi matematis siswa kelas V SD Islam Al-Musyarrofah. Hasil penelitian ini diharapkan ini dapat berguna bagi pihak-pihak terkait yang dapat memanfaatkannya seperti kepala sekolah, guru, siswa, serta peneliti selanjutnya. $(S D)$

Kata kunci: Model Pembelajaran PBL, Kemampuan Representasi Matematis, Sekolah Dasar

\section{PENDAHULUAN}

Ilmu pengetahuan ialah upaya sadar yang dilaksanakan oleh manusia demi memahami dan meningkatkan pengetahuan dari berbagai disiplin ilmu. Dalam semua tingkat satuan pendidikan matematika itu salah satu mata pelajaran yang perlu didapatkan oleh tiap siswa sebab matematika itu pelajaran yang mempunyai tujuan kurikuler untuk mendukung tercapainya tujuan dari pembelajaran nasional. Hasil PISA (Programme for International Student Assessment) tahun 2018 menyebutkan bahwa Indonesia mengalami penurunan di segala bidang, khususnya dalam matematika. Pada tahun 2015 Indonesia memiliki rata-rata skor 463,4 di bidang matematika dan mengalami penurunan di tahun 2018 dengan rata-rata skor 458,3 dari 72 negara yang dinilai (Dewabrata, 2019). Selanjutnya menurut data 
TIMSS (Trends International Mathematics and Science Study), di tahun 2015 diketahui bahwa posisi Indonesia terletak di posisi ke 44 dari 49 negeri dengan memperoleh point rata-rata sebesar 397 (Novaliosi, 2019: 563).

Dari studi tersebut dapat dikemukakan rendahnya kemampuan dalam menuntaskan soal-soal yang tidak tersusun secara sistematis yang dimiliki pelajar di Indonesia, yang berkenaan dengan pembenaran, penyelesaian permasalahan yang menggunakan penalaran matematika, menciptakan konjektur ataupun generalisasi, serta menciptakan ikatan antara kenyataan serta informasi yang disajikan.

Bersumber pada kenyataan yang disebutkan di atas dapat dikatakan bahwa kemampuan berfikir kritis, kreatif, kemampuan memecahkan masalah, dan kemampuan representasi matematis siswa masih termasuk rendah. Hal ini disebabkan pelajaran matematika yang berlangsung di sekolah tidak sering mengajak siswa untuk berfikir kritis dalam menyelesaikan suatu permasalahan. Guru beranggapan bahwa siswa tidak mampu menggunakan rumus untuk memecahkan persoalan yang diberikan. Matematika merupakan pelajaran yang seharusnya mampu menumbuhkan sifat logis dan kritis pada siswa karena dapat berguna untuk kehidupan mereka sehari-hari. Keterampilan berpikir pada pembelajaran matematika berkaitan dengan kemampuan matematis untuk menghadapi masalah dalam bentuk matematika serta dalam kehidupan setiap hari yang meliputi kemampuan pemecahan permasalahan, kemampuan berkomunikasi, kemampuan berpendapat, kemampuan berkoneksi, maupun kemampuan representasi.

Representasi ialah wujud interpretasi siswa yang bisa digunakan seperti alat bantu untuk menyelesaikan permasalahan terhadap sebuah persoalan. Penerapan representasi dapat menolong siswa dalam menyelesaikan permasalahan yang pada awal mulanya nampak susah tetapi pada ujungnya dapat dituntaskan dengan mudah. Pembelajaran di kelas yang terjadi saat ini tidak memberikan peluang bagi siswa untuk mencoba merepresentasi pemahaman sebuah konsep tetapi guru hanya memfokuskan pada pemahaman siswa saja sehingga siswa belum memiliki kemampuan representasi yang baik dan optimal.
Hasil penelitian yang dilakukan oleh Handayani dan Juanda, dalam Ismawati (2019: 3), menunjukan bahwa kemampuan representasi matematis siswa sekolah dasar di Kecamatan Sumedang Utara hanya mencapai $24,9 \%$. Menyadari betapa pentingnya kemampuan representasi matematis siswa, maka cara yang dapat digunakan untuk mengembangkan kemampuan tersebut perlu direncanakan agar siswa dapat memiliki kemampuan representasi dengan baik.

Dalam kegiatan belajar mengajar yang terjadi saat ini siswa dituntut untuk selalu belajar, tetapi guru sedikit memberikan pelajaran tentang bagaimana siswa itu belajar. Pembelajaran berbasis masalah dapat membuat siswa berfikir secara kritis dalam menghadapi berbagai persoalan dan mendapatkan pengetahuan baru. Siswa akan dihadapkan pada persoalan dalam kegiatan pembelajaran sehingga akan membuat siswa menjadi aktif karena adanya tantangan untuk memecahkan persoalan dengan cara menganalisis serta mengumpulkan informasi sehingga siswa mendapatkan solusi untuk menyelesaikan permasalahan yang ada.

Bagaimana menjalin komunikasi yang baik dengan para siswa?, dan bagaimana menemukan model pembelajaran yang terbaik serta bijaksana untuk dipakai dalam proses pembelajaran di kelas?. Untuk menangani permasalahan yang sudah disebutkan di atas, maka kemampuan representasi siswa harus diperbaiki dan juga ditingkatkan dengan menggunakan strategi ataupun model pembelajaran yang tepat sehingga kemampuan representasi siswa meningkat.

Hal ini dapat dijalankan dengan membiasakan siswa untuk berlatih mencari solusi dari sebuah masalah yang ada sehingga bisa membentuk pola pikir siswa supaya lebih kritis serta dapat melatih kemampuan representasinya. Representasi digunakan secara luas dalam bidang matematika sebab representasi bisa menolong siswa untuk berbagi, meningkatkan, dan menyajikan kondisi permasalahan nyata ke dalam bahasa matematis. Untuk itu guru harus meningkatkan dan melatih siswa dalam menumbuhkan keahlian representasinya untuk menuntaskan sesuatu permasalahan yang diberikan. 


\section{KAJIAN LITERATUR}

Menurut Sabirin dalam Sanjaya (2018: 61) Representasi ialah wujud interpretasi siswa yang dapat digunakan seperti alat bantu untuk menyelesaikan permasalahan terhadap sebuah persoalan. Selanjutnya representasi matematis merupakan penerjemahan, penggambaran, penunjukan kembali, pengungkapan, pelambangan dan pemodelan dari sebuah ide, konsep matematik, maupun ide serta hubungannya dalam suatu konstruksi, konfigurasi, dan situasi permasalahan tertentu yang ditunjukkan siswa dalam wujud yang bermacam-macam untuk mendapat kejelasan makna, menemukan penafsirannya, dan menemukan solusi dari permasalahan yang diberikan (Rangkuti, 2014: 112).

Dengan demikian kemampuan representasi ialah bagian dari kemampuan berpikir pada tingkatan yang tinggi dalam matematika, sebab kemampuan representasi berkaitan dengan kemampuan berkomunikasi yang direpresentasikan dalam bentuk grafik, gambar, diagram, ataupun bentuk representasi lain dan dapat dipakai sebagai alat bantu untuk menuntaskan permasalahan. Representasi sering digunakan ketika siswa sedang belajar matematika. Oleh karena itu dengan bermacammacam kemampuan representasi yang ditimbukan oleh siswa, maka hal tersebut diharapkan dapat menjadi sebuah gagasan, atau strategi yang dikomunikasikan pada guru maupun temannya saat mereka berinteraksi di dalam kelas.

Dahlan dan Juandi dalam Nurbaiti dan Hayyun (2017: 225) menyatakan bahwa representasi bermanfaat bagi siswa sesuai dengan taraf kognitifnya, yaitu :

a) Pada tingkatan sekolah dasar, representasi bermanfaat untuk menyusun ide-ide matematika dalam bentuk yang lebih konkrit.

b) Pada tingkatan sekolah menengah, representasi bermanfaat dalam pemecahan masalah, memperluas, ataupun menafsirkan ide-ide matematika. Diawali dari pengumpulan data, menyusun grafik ataupun tabel, hingga pada pengembangan representasi simbolik (aljabar).

\section{Indikator kemampuan representasi matematis}

Dalam mengukur keberhasilan kemampuan representasi, maka indikator kemampuan representasi yang dijadikan acuan sebagai berikut :

\section{Visual dalam Wujud Gambar, Grafik atau Diagram dan Tabel}

a. Menampilkan kembali data maupun informasi dari permasalahan yang diberikan ke dalam wujud foto, diagram ataupun grafik, serta tabel.

b. Memanfaatkan representasi visual untuk mengatasi sebuah permasalahan.

c. Memperjelas pemecahan masalah dengan membuat gambar pola.

\section{Ekspresi (Simbol) Matematika ataupun Persamaan Matematika}

d. Membuat persamaan matematika ataupun model matematika berdasarkan permasalahan yang dibagikan.

e. Menuntaskan permasalahan memakai ekspresi matematika.

f. Membuat konjektur dari pola yang disajikan.

\section{Deskripsi ataupun Pernyataan}

g. Membuat situasi permasalahan berdasarkan permasalahan yang diberikan

h. Menjabarkan representasi serta interpretasi

i. Menuliskan pemecahan permasalahan secara tertulis melalui perkataan.

j. Mempergunakan tahap-tahap penyelesaian matematika dalam beberapa kata.

Salah satu cara yang dapat dilakukan dalam mengembangkan kemampuan representasi yaitu dengan menerapkan model PBL. Model PBL menurut (Kamilah dkk, 2019:71) adalah model pembelajaran yang diarahkan untuk menuntaskan berbagai permasalahan terutama yang berhubungan dengan materi pelajaran dalam kehidupan nyata. Dalam model pembelajaran PBL siswa harus menemukan apa yang tidak dipahami serta apa yang dipahami dan juga belajar untuk menyelesaikan suatu masalah. 
Siswa yang dapat menyelesaikan permasalahan tersebut adalah siswa yang menguasai ilmu matematika. dengan demikian ketika siswa sudah menguasai konsep matematika, maka ia dapat menggunakannya dalam kehidupan sehari-hari untuk menyelesaikan masalah yang mereka hadapi. Sebagai tenaga pendidik, seorang pendidik diharuskan untuk dapat mengimplementasikan sebuah model pembelajaran yang baik supaya proses pembelajaran dapat dilaksanakan secara tersusun dan terencana sehingga tercapainya tujuan pembelajaran yang diharapkan.

Menurut Joyce \& Weil dalam Wijanarko, (2017: 53) model pembelajaran ialah sebuah pola ataupun rencana yang dapat dipakai untuk membuat rancangan pembelajaran secara terus menerus (kurikulum), membimbing proses belajar mengajar di kelas serta merancang bahan- bahan untuk digunakan saat pembelajaran. Selanjutnya menurut Hamzah dan Muhlisrarini dalam Duri (2019: 21) model pembelajaran itu suatu rancangan proses belajar mengajar yang dapat dipakai sebagai petunjuk untuk melakukan kegiatan tersebut.

Kurikulum merancang persoalanpersoalan yang mewajibkan siswa agar memperoleh ilmu yang berarti sehingga siswa dapat menuntaskan suatu persoalan dan mempunyai strategi belajar sendiri. Proses pembelajaran memakai pendekatan yang terencana untuk menyelesaikan permasalahan ataupun menghadapi tantangan yang dibutuhkan dalam kehidupan nyata setiap hari nanti.

Dalam hal ini PBL memberikan peluang kepada siswa dalam berpikir analitis serta kritis untuk menemukan serta memakai sumber belajar yang sesuai. Kemudian PBL menurut Ibrahim dalam Rosidah, (2018:63) berpendapat bahwa PBL merupakan pengembangan keterampilan berpikir dan penyelesaian masalah yang dilakukan melalui pembelajaran. Tidak hanya itu, siswa butuh dibimbing juga agar dapat menuntaskan permasalahan, mendapatkan jalan keluar untuk dirinya serta berupaya untuk merealisasikan ide-idenya agar siswa mampu memahami dan menerapkan pengetahuannya.

Oleh sebab itu, pembelajaran yang terjadi wajib membagi peluang bagi murid agar mengonstruksi pengetahuan dalam proses berpikirnya. Model pembelajaran berdasarkan masalah ini bercirikan dengan memakai permasalahan yang nyata pada ulasan materi. Model ini lebih menarik, menantang, dan melatih siswa untuk mengalami masalahmasalah yang ditemui serta mencari jalan keluar terbaik dalam penyelesaiannya.

Tiap-tiap model pembelajaran mempunyai kelebihan dan kekurangan. Kelebihan model pembelajaran PBL dalam (Wulandari, B, 2013: 182) yakni:

a) Penyelesaian permasalahan di PBL cukup bagus untuk menguasai materi.

b) Penyelesaian permasalahan berlangsung selama pembelajaran itu beroperasi serta menantang kemampuan siswa serta memberikan kepuasan kepada siswa.

c) PBL dapat mengembangkan kegiatan belajar mengajar pada siswa.

d) Meringankan siswa dalam proses transfer untuk menguasai permasalahan dalam kehidupan setiap hari.

e) Menolong siswa dalam meningkatkan pemahamannya serta menolong siswa agar mempertanggung jawabkan pembelajarannya sendiri.

f) Menolong siswa dalam menguasai hakikat belajar sebagai metode berpikir, tidak hanya paham pembelajaran yang guru sajikan dalam buku.

g) PBL menghasilkan area belajar mengajar yang mengasyikkan serta disukai siswa.

h) Memungkinan diterapkan dalam kehidupan nyata

i) Menstimulus siswa dalam menuntut ilmu dengan terus menerus.

Selain memiliki kelebihan, menurut Sanjaya dalam Nuraini, (2017: 372) model pendidikan PBL mempunyai kelemahan, antara lain:

a) Siswa merasa ragu untuk mencoba karena tidak mempunyai atensi serta keyakinan bahwa permasalahan yang dipelajari susah untuk diselesaikan.

b) Memerlukan waktu yang cukup untuk persiapan model PBL demi mencapai kesuksesan model tersebut.

c) Siswa tidak ingin mempelajari apa yang ingin mereka pelajari tanpa adanya alasan mengapa mereka berupaya untuk menyelesaikan permasalahan yang lagi dipelajari. 
Menurut Rosidah (2018:65), ada lima tahap utama dalam menerapkan model pembelajaran PBL, sebagai berikut:

\section{Orientasi siswa terhadap masalah}

Dalam sesi ini, pendidik menyatakan penjelasan mengenai tujuan belajar, kebutuhan/peralatan yang diperlukan dan memberikan motivasi/dorongan pada siswa supaya berpartisipasi aktif dalam tiap tahapan kegiatan pemecahan masalah.

\section{Mengorganisasi siswa dalam belajar}

Pada sesi ini, guru mengorganisasikan siswa lewat pemberian pertolongan dalam membuat definisi dan organisasi tugas belajar yang berkaitan dengan pemecahan permasalahan.

\section{Bimbingan observasi individu ataupun berkelompok}

Pada sesi ini, guru memotivasi serta mengarahkan siswa dalam mengumpulkan data yang sesuai. Tidak hanya itu, guru membimbing siswa dalam melaksanakan eksperimen juga untuk mendapatkan uraian penyelesaian permasalahan.

\section{Pengembangan serta penyajian hasil karya}

Pada sesi ini, guru mengarahkan siswa dalam membuat rancangan serta persiapan presentasi hasil karya berdasarkan laporan pemecahan permasalahan semacam prototipe, video, foto, dokumen, presentasi, dan lain sebagainya.

\section{Analisis serta penilaian proses pemecahan permasalahan}

Pada sesi ini, guru membimbing siswa dalam proses refleksi dan penilaian terhadap proses pengamatan dalam penyelesaian permasalahan yang sudah dilakukan

\section{METODE PENELITIAN}

Penelitian ini menggunakan pendekatan kuantitatif yang berpandangan bahwa pengetahuan ilmiah adalah pengetahuan yang berawal dan didasarkan pada pengalaman (experience) yang tertangkap lewat pancaindera untuk kemudian diolah oleh nalar (Suradika dan Wicaksono, 2019:32). Metode yang digunakan adalah metode kuasi eksperimen, dengan desain nonequivalen control group design. Penelitian ini dilakukan di SD Islam Al- Musyarrofah di Jl. H. Muchtar Raya, Gg H. Rebo, Rt 012/011 No.95, Kelurahan Petukangan Utara, Kecamatan Pesanggrahan, Jakarta Selatan, Kode Pos 12260. Penelitian ini dilaksanakan di semester ganjil yaitu pada bulan November 2020 Tahun Pelajaran 2020/2021.

Populasi dari penelitian ini adalah siswa kelas V SD Islam Al-Musyarrofah dengan jumlah 42 siswa yang terdiri dari rombongan belajar VA dan VB. Sampel yang digunakan dalam penelitian ini adalah kelas VA sebagai kelas eksperimen dan kelas VB sebagai kelas kontrol. Jumlah siswa di kelas VA adalah 22 orang dan jumlah siswa di kelas VB adalah 20 orang. Teknik pengambilan sampel yang dipakai pada penelitian ini menggunakan teknik non random jenis purposive sampling. Teknik pengumpulan data dalam penelitian ini yaitu dengan melakukan observasi, tes dan dokumentasi. Instrumen tes yang digunakan yaitu berupa soal dan postest yang sudah dilakukan validasi oleh expert judgment. Reliabilitas yang diperoleh menunjukan alat ukur kemampuan representasi dapat diandalkan. Kemudian dilakukan observasi untuk melihat kemajuan pada tiap- tiap pertemuan dan dokumentasi untuk memperkuat keabsahan sebuah data. Analisis uji beda dilakukan dengan menggunakan Uji-T Independent Sample. Uji ini digunakan untuk melihat serta meninjau pengaruh perlakuan. Pada uji ini memakai rata-rata (mean) dua kelompok, yakni kelompok eksperimen dan kelompok kontrol. Adapun kriteria dalam pengambilan keputusan adalah sebagai berikut:

a) Jika nilai sig. (2 tailed) $<0,05$ maka $\mathrm{H}_{1}$ diterima

b) Jika nilai sig. (2 tailed) $>0,05$ maka $\mathrm{H}_{0}$ diterima $\mathrm{H}_{1}$ ditolak.

\section{PENGAMBILAN KEPUTUSAN}

Pengambilan keputusan dalam penelitian ini memakai uji perbandingan rata-rata dengan memakai uji t-independent sample dengan software SPSS tipe 20 dengan asumsi kedua varians homogen dengan taraf signifikansi 0,05 . Adapun syarat pengujiannya yaitu :

a) Jika nilai signifikansi (2 tailed) $<0,05$ disimpulkan ada perbedaan yang signifikan antara kelas eksperimen dengan kelas kontrol. 
b) Jika nilai signifikansi (2 tailed) $>0,05$ disimpulkan tidak ada perbedaan yang signifikan antara kelas eksperimen dengan kelas control.

Bersumber pada hasil uji t yang memakai Independent Sample Test didapatkan skor $\mathrm{t}$ hitung sebanyak 3,497 yang artinya lebih besar dari t tabel 2.021, dengan taraf signifikansi $0,001<0,05$, hal ini berarti bahwa ada perbedaan yang signifikan antara siswa di kelas eksperimen dengan siswa di kelas kontrol. Dengan demikian dapat disimpulkan terdapat pengaruh model pembelajaran Problem Based Learning terhadap kemampuan representasi matematis siswa kelas $\mathrm{V}$ SD Islam AlMusyarrofah. membuat siswa berperan lebih aktif, kritis, mandiri, serta bertanggung jawab terhadap apa yang mereka pelajari. Selain itu siswa lebih berani mengemukakan pendapat, berpikir kritis, dan proses pembelajaran berjalan secara multi arah karena ada interaksi dengan teman sekelompok untuk bertukar pemikiran dengan anggota kelompok yang lain bukan hanya dengan guru saja.

e) kemampuan representasi matematis siswa menjadi lebih baik karena diterapkannya model PBL sehingga siswa dilatih untuk belajar menyelesaikan pemasalahan baik secara individu ataupun berkelompok.

Table 1Uji-T Independent

\begin{tabular}{|c|c|c|c|c|c|c|c|c|c|c|}
\hline & \multicolumn{2}{|c|}{$\begin{array}{c}\text { evene's Test for } \\
\text { Equality of } \\
\text { Variances }\end{array}$} & \multicolumn{7}{|c|}{ t-test for Equality of Means } \\
\hline & & \multirow[t]{2}{*}{$F$} & \multirow[t]{2}{*}{ Sig. } & \multirow[t]{2}{*}{$T$} & \multirow[t]{2}{*}{$d f$} & \multirow{2}{*}{\begin{tabular}{|c|} 
Sig. (2- \\
taile \\
d)
\end{tabular}} & \multirow{2}{*}{$\begin{array}{c}\text { Mean } \\
\text { Differe } \\
\text { nce }\end{array}$} & \multirow{2}{*}{$\begin{array}{c}\text { Std. Error } \\
\text { Differe } \\
\text { nce }\end{array}$} & \multicolumn{2}{|c|}{$\begin{array}{c}95 \% \text { Confidence Interva } \\
\text { of the Difference }\end{array}$} \\
\hline & & & & & & & & & Lower & Upper \\
\hline $\begin{array}{l}\text { HA } \\
\text { SIL }\end{array}$ & $\begin{array}{l}\begin{array}{l}\text { Equal } \\
\text { variances } \\
\text { assumed }\end{array} \\
\text { Equal } \\
\text { variances not } \\
\text { assumed }\end{array}$ & $\begin{array}{c}2,43 \\
7\end{array}$ &, 126 & 3,497 & $\begin{array}{c}37 \\
107\end{array}$ & ,001 & , 14057 & ,03948 &, 06059 &, 22056 \\
\hline
\end{tabular}

\section{KESIMPULAN}

a) Berdasarkan hasil analisis dan uji statistik pada pembahasan sebelumnya, maka dapat ditarik kesimpulan sebagai berikut : Model PBL berpengaruh terhadap kemampuan representasi matematis siswa sekolah dasar.

b) Terdapat perbedaan yang signifikan antara siswa di kelas eksperimen dengan siswa di kelas kontrol

c) Skor akhir kemampuan representasi matematis siswa di materi denah dan skala antara kelas eksperimen serta kelas kontrol menunjukan kalau skor rata-rata kelas eksperimen lebih tinggi dibandingkan kelas kontrol.

d) Dengan diterapkannya model pembelajaran Problem Based Learning

\section{REFERENSI}

Dewabrata, M. (2019). Hasil PISA 2018 Resmi Diumumkan, Indonesia Alami Penurunan Skor Di Setiap Bidang. (https://www.zenius.net/blog/23169/ pisa 201822019standar-internasional, diakses 01 Februari 2020).

Duri, B.A. (2019). Pengaruh Model Pembelajaran Auditory Intellectually Repetition terhadap Hasil Belajar Matematika Siswa di Sekolah Dasar. Fakultas Ilmu Pendidikan. Universitas Muhammadiyah Jakarta (tidak dipublikasikan).

Hadi, S dan Novaliosi. (2019). TIMSS (Trends In International Mathematic and Science Study) 
http://jurnal.unsil.ac.id/index.php/snc $\mathrm{p} /$ article/view/196/754 , diakses 563 pada 01 Februari 2020). Hal:

Ismawati. (2019). Perbandingan Penggunaan Media Pembelajaran Augmented Reality dan Pasir Kinetik dalam Meningkatkan Kemampuan Representasi Matematis Siswa Sekolah Dasar. Skripsi. Fakultas Ilmu Pendidikan. Universitas Muhammadiyah Jakarta (tidak dipublikasikan).

Kamilah, S.R, Puji, B., \& Iwan G. (2019). Penerapan Model Pembelajaran Problem Based Learning (PBL) dengan Berbantuan Geogebra untuk Meningkatkan Kemampuan

Representasi Matematis Siswa Sekolah Dasar. Jurnal Pendidikan dan Pembelajaran Matematika. Volume 4 (2): 71.

Nuraini, F. (2017). Penggunaan Model Problem Based Learning (PBL) untuk Meningkatkan Hasil Belajar IPA Siswa Kelas 5 SD. E-jurnal Mitra Pendidikan. Volume 1 (4): 371-372.

Rangkuti, A.N. (2014). Representasi Matematis. Forum Pedagogik. Volume 6 (1): 112-113.

Rosidah, C.T. (2018). Penerapan Model Problem Based Learning untuk Menumbuhkembangkan Higher Order Thinking Skill Siswa Sekolah Dasar. Jurnal Inventa. Volume 2 (1): 63,65 .

Sanjaya, I.I., Maharani, H.M \& Basir, M.A. (2018). Kemampuan Representasi Matematis Siswa pada Materi Lingkaran Berdasar Gaya Belajar Honey Mumfrod. Penelitian Didaktik Matematika. Volume 2(2): 61.

Suradika, Agus dan Wicaksono, Dirgantara. (2019), Metodologi Penelitian, Jakarta: UM Jakarta Press.

Widyasari, N \& Hayyun, M. (2017). Pengembangan Pembelajaran Matematika SD. Jakarta : Fakultas Ilmu Pendidikan Universitas Muhammadiyah Jakarta.
Wijanarko, Y. (2017). Model Pembelajaran Make A Match untuk Pembelajaran IPA yang Menyenangkan. Jurnal Taman Cendekia. Volume 1 (1): 53

Wulandari, B. (2013). Pengaruh ProblemBased Learning terhadap Hasil Belajar Ditinjau dari Motivasi Belajar PLC di SMK. Jurnal Pendidikan Vokasi. Volume 3 (2): 181-182 